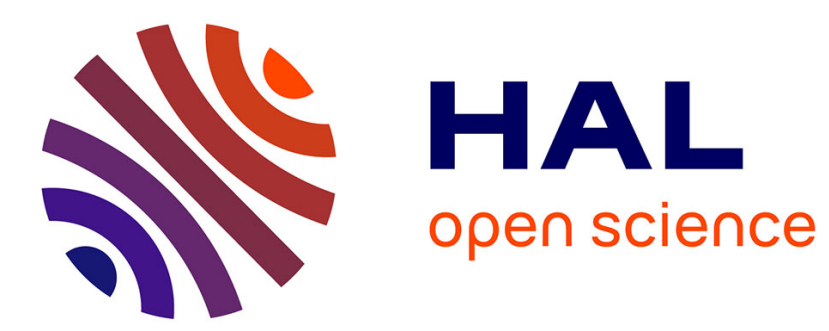

\title{
The Semiotics of Sport Heroism
}

Pascal Duret, Marion Wolff

\section{To cite this version:}

Pascal Duret, Marion Wolff. The Semiotics of Sport Heroism. International Review for the Sociology of Sport, 1994, 29 (2), pp.135-148. 10.1177/101269029402900202 . hal-01758862

\section{HAL Id: hal-01758862 https://hal-insep.archives-ouvertes.fr/hal-01758862}

Submitted on 4 Apr 2018

HAL is a multi-disciplinary open access archive for the deposit and dissemination of scientific research documents, whether they are published or not. The documents may come from teaching and research institutions in France or abroad, or from public or private research centers.
L'archive ouverte pluridisciplinaire HAL, est destinée au dépôt et à la diffusion de documents scientifiques de niveau recherche, publiés ou non, émanant des établissements d'enseignement et de recherche français ou étrangers, des laboratoires publics ou privés. 


\title{
The Semiotics of Sport Heroism
}

Pascal Duret, Marion Wolff

Laboratoire de Sociologie du Sport, Institut National du Sport et de L'Education Physique, 11 Avenue du Tremblay, Paris France

\begin{abstract}
Semiological analysis helps to construct a theory of mechanisms by which sports champions are celebrated. The study of correlations between "heroism" and "performance" in marks of 21 champions given by "L'Equipe" readers, shows for narrative organisation:

- the champion facing adversity

- the champion unfairness

- the account of the hero's quest

- the champion who shed his blood to become greater

In any case, it is not the result, but the way of winning or losing which makes a hero.

Key words: champions, heroes, semiology, spectacle.
\end{abstract}

When glancing at the list of leading sports personalities regularly published in the paper "L'Equipe", the reader finds himself in a Lewis-Carrol-fashion universe where champions change their size, smaller or larger. These concepts of "greatness" and "symbolic size" directly refer to the ways in which the champions succeed in captivating a number (the largest possible number) of spectators. But what exactly makes an exploit great? How do some champions rise to the status of heroes? What is sport heroism made of? Is winning possible without being magnified? Is losing possible without getting smaller? An athlete has become really heroic only when the crowd has the feeling that it owes him something. We can tell a hero from an ordinary champion by his ability to stir up the emotions of others. By examining the skill and the style involved in becoming greater, we should be able to more fully understand the economies of heroic debt. In our endeavour to pursue this course, we must accept not to proceed in fairy-tale manner, so as to be able to describe the processes by which our champions are glorified. Our intention is therefore not to begin an ontological argument between the prospective strengths of the champion and the hero as individuals. Rather, we intend to use the "modal semiotics analysis" (Greimas and Fontanille 1991), in order to grasp the processes used by the specialized commentators when presenting the exploit and the effects that these commentators may have on public opinion. We shall therefore be looking primarily at stage-setting, rhetoric and semiotics.

\section{Concerning the Method}

We carried out a survey of 64 almost-daily readers ${ }^{1}$ of "L'Equipe magazine" in the I.N.S.E.P. library. The same survey was repeated after a two-month interval. The task involved awarding two marks to each of the champions appearing in a list of 21 . The first mark, for "performance", is portrayed as marking the sports achievement. The second mark, for "heroism" is portrayed as a way of accounting for the manner in which the achievement was accomplished. Instead of concentrating our efforts on the resulting "bit-parades", we have instead worked on analysing the correlations between the marks, which enables us to group the athletes in pairs. In order to see what these pairs have in commong, it is necessary to go back to the reading corpus of the subjects (l'Équipe magazine). The analysis of the contents allows us to highlight the common theme of each pair. Each association is supposed relate a specific story. Each athlete personifies a "character". With this status of "typical character", the semiotic analysis can be differentiated from the simple analysis of classic contents. This is the reason why the subjects express either admiration or deprecation.

\section{Brief Analysis of the "Hit-Parade"}

A striking similarity exists between the marks given in October and in December. With the exceptions of Leconte and Forget (the effect of context is analysed below), the champions have an average difference of Jess than one point between the two entries. With regard to "performance", two of the three favourites from October come within the first three positions in December: Arthaud and Lewis, 
with forget replacing Edberg. As for marks of "heroism", Connors, Rives and Daboville come in first in October as well as in December. C. Lewis and M. Tyson are the only champions with a difference of Jess than one point between "performance" and "heroism", each concept representing an irreductible form of the sports exploit, each endowed with a different status. The heroism mark corresponds to the notion of the notion of the extreme (marks under 5 and over 15 were given). The performance is characterised by Jess lower marks (on average, 4 points separate the first from the last). These marks are Jess spread out than the average heroism mark (from 5,635 to 15,079).

\section{Figure 1}

\begin{tabular}{|l|c|c|c|c|}
\hline 1o vote/October & $\begin{array}{l}\text { average of the } \\
\text { performance's } \\
\text { marks }\end{array}$ & $\begin{array}{l}\text { standard } \\
\text { deviation }\end{array}$ & $\begin{array}{l}\text { average of the } \\
\text { heroism's } \\
\text { marks }\end{array}$ & $\begin{array}{l}\text { standard } \\
\text { deviation }\end{array}$ \\
\hline ARTHAUD & 13,60 & 3,685 & 11,85 & 3,953 \\
\hline CANTONNA & 10,333 & 3,432 & 7,46 & 3,687 \\
\hline CONN ORS & 11,794 & 3,058 & 14,84 & 4,332 \\
\hline FERNANDE & 10,698 & 2,885 & 7,71 & 3,883 \\
\hline FORGET & 12,413 & 3,297 & 10,74 & 3,998 \\
\hline
\end{tabular}

1 only readers who claimed to buy L''Equipe" more than three times a week were able to participate.

\section{Figure 2}

\begin{tabular}{|l|c|c|c|c|}
\hline JOHNSON & 10,175 & 2,596 & 7,540 & 3,966 \\
\hline LEMOND & 11,556 & 2,923 & 12,524 & 4,538 \\
\hline DUCHESNA & 12,841 & 3,383 & 14,111 & 4,216 \\
\hline LEWIS & 13,111 & 3,393 & 13,374 & 3,865 \\
\hline RIVES & 12,286 & 3,221 & 15,079 & 4,504 \\
\hline PAPIN & 12,937 & 2,564 & 10,492 & 3,882 \\
\hline POULIDOR & 10,556 & 2,689 & 12,429 & 3,923 \\
\hline PROST & 11,746 & 3,109 & 10,429 & 4,025 \\
\hline LECONTE & 9,159 & 2,954 & 5,635 & 3,768 \\
\hline SENNA & 11,810 & 2,678 & 7,508 & 3,463 \\
\hline TIOZZO & 10,857 & 2,971 & 12,270 & 3,568 \\
\hline TYSON & 11,651 & 2,986 & 12,381 & 3,687 \\
\hline EDBERG & 13,063 & 3,453 & 11,556 & 4,219 \\
\hline PATISSIER & 11,238 & 2,754 & 9,079 & 3,654 \\
\hline EDLINGER & 11,856 & 3,023 & 13,683 & 3,614 \\
\hline D'ABOVILL & 12,886 & 3,356 & 14,587 & 4,203 \\
\hline
\end{tabular}


Figure 3

\begin{tabular}{|l|c|c|c|c|}
\hline $2^{\circ}$ vote/December & $\begin{array}{l}\text { average of the } \\
\text { performance's } \\
\text { marks }\end{array}$ & $\begin{array}{l}\text { standard } \\
\text { deviation }\end{array}$ & $\begin{array}{l}\text { average of the } \\
\text { heroism's } \\
\text { marks }\end{array}$ & $\begin{array}{l}\text { standard } \\
\text { deviation }\end{array}$ \\
\hline ARTHAUD & 13,452 & 3,482 & 11,61 & 3,568 \\
\hline CANTONNA & 10,126 & 3,812 & 7,96 & 3,463 \\
\hline CONNORS & 11,612 & 3,345 & 15,24 & 4,198 \\
\hline FERNANDEZ & 11,226 & 3,133 & 7,11 & 3,562 \\
\hline FORGET & 13,865 & 3,006 & 11,21 & 3,998 \\
\hline JOHNSON & 10,153 & 2,123 & 8,05 & 4,162 \\
\hline LEMOND & 11,365 & 3,058 & 12,98 & 4,354 \\
\hline DUCHESNAY & 12,655 & 3,059 & 14,34 & 3,995 \\
\hline LEWIS & 13,235 & 3,121 & 13,89 & 3,996 \\
\hline RIVES & 12,563 & 3,037 & 15,35 & 4,698 \\
\hline PAPIN & 13,284 & 2,022 & 10,56 & 2,965 \\
\hline POULIDOR & 10,875 & 2,315 & 12,03 & 3,642 \\
\hline PROST & 11,230 & 3,024 & 10,02 & 3,869 \\
\hline LECONTE & 11,236 & 3,452 & 9,63 & 3,778 \\
\hline SENNA & 11,023 & 2,912 & 7,76 & 3,259 \\
\hline TIOZZO & 10,956 & 2,453 & 12,15 & 3,742 \\
\hline TYSON & 11,988 & 2,478 & 12,86 & 3,153 \\
\hline EDBERG & 13,256 & 3,125 & 11,98 & 3,976 \\
\hline PATISSIER & 11,246 & 2,983 & 9,56 & 3,245 \\
\hline EDLINGER & 11,130 & 2,465 & 13,81 & 3,216 \\
\hline D'ABOVILLE & 13,126 & 3,254 & 15,23 & 4,147 \\
\hline
\end{tabular}

\section{The Narrative Frameworks Stemming from the Correlation}

Between the performance and the judgement of heroism that it inspires, there is a real "semiotic gap" (Greimas 1983, p. 18) which is filled as soon as certain champions are glorified. This process of "heroisation" will now be examined by analysing the groups made by correlation. Marks given to the champions do not have identical relationships among themselves. Amongst groups of champions meaningful at 0.01 , the correlations between heroism are systematically closer to 1.00 . 


\section{Figure 4}

\begin{tabular}{|l|c|c|c|}
\hline \multicolumn{1}{|c|}{ pairs of champions } & $\begin{array}{l}\text { Coefficient of } \\
\text { correlation } \\
\text { Bravais- }\end{array}$ & DDL & Probability \\
\hline Leconte performance/Leconte héroïsme & 0,539 & 19 & .0 .25 \\
\hline Leconte performance/Connors héroïsme & 0,496 & 19 & .05 \\
\hline Leconte hérö̈sme/Connors performance & 0,564 & 19 & .01 \\
\hline Leconte héroïsme/Connors héroïsme & 0,946 & 19 & .001 \\
\hline Connors héroïsme/Connors Performance & 0,624 & 19 & .01 \\
\hline Duschesnay Hérö̈sme/Duschesnay Performance & 0,601 & 19 & .01 \\
\hline Duschesnay performance/Cantona performance & 0,532 & 19 & .025 \\
\hline Duschesnay performance/Cantona héroïsme & 0,654 & 19 & .01 \\
\hline Duschesnay héroïsme/Cantona performance & 0,763 & 19 & .001 \\
\hline Duschesnay héroïsme/Cantona héroïsme & 0,909 & 19 & .001 \\
\hline Cantona héroïsme/Cantona performance & 0,556 & 19 & .01 \\
\hline Rives performance/Rives héroïsme & 0,634 & 19 & .01 \\
\hline Rives performance/Tiozzo performance & 0,542 & 19 & .01 \\
\hline Rives performance/Tiozzo héroïsme & 0,576 & 19 & .01 \\
\hline Rives hérö̈sme/Tiozzo Performance & 0,725 & 19 & .001 \\
\hline Tiozzo Héroïsme/Tiozzo performance & 0,482 & 19 & .05 \\
\hline Rives héroïsme/Tiozzo héroïsme & 0,896 & 19 & .001 \\
\hline D'Aboville performance/D'Aboville hérö̈sme & 0,522 & 19 & .025 \\
\hline D'Aboville performance/Arthaud performance & 0,677 & 19 & .001 \\
\hline D'Aboville héroïsme/Arthaud performance & 0,543 & 19 & .01 \\
\hline D'Aboville héroïsme/Arthaud héroïsme & 0,925 & 19 & .025 \\
\hline Arthaud héroïsme/Arthaud performance & 0,634 & 19 & .01 \\
\hline
\end{tabular}




\section{Figure 5}

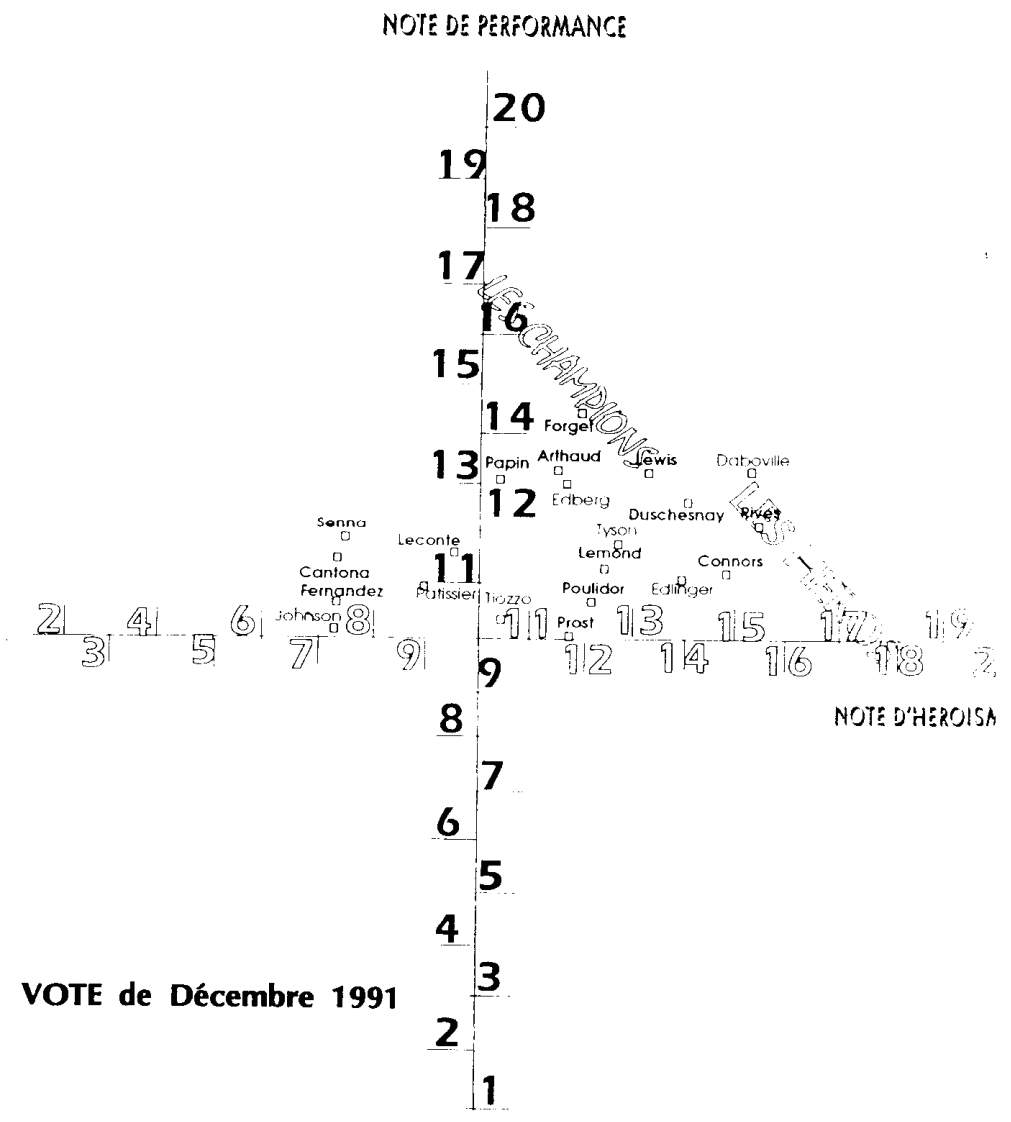

The strongest correlations do not necessarily group together champions in the same field, but do concern the same champions in October and December. It is important to point out that strong correlations do not necessarily stem from similar heroism marks. For example, in October, Leconte and Connors are at opposite extremes, as are Cantona and the Duchenay's. What signals do these four groups of champions send us?2 They relate four accounts: the account of becoming greater by resisting in the face of adversity (Connors/Leconte), the account of becoming greater through injustice (Cantona/the Duchenay's), the account of heroes of pursuit (Arthaud/Daboville), and finally the account of heroes who shed the ir blood to become great er (Rives/Tiozzo ).

\section{Connors/Leconte: Resisting in the Face of Difficulty Equals Sticking to One's Commitments}

Connors and Leconte teach us that it is not the victory but the pursuit of honor that makes a hero. The struggle for honour represents a paradoxical battle, a possible victory in defeat, the possible delight of morally reversing the results of the match. The fact that one is beaten in a match certainly constitutes a test for anyone finding himself in this position, thus enabling him to be placed on the scale of moral greatness. ${ }^{3}$ The heroic figure cannot bear the absence of resistance. Regardless the way things are going, he must above all never diminish his ardour. It does not matter if he loses, provided he avoids collapsing or breaking up. It is of little importance if courage does not lead to victory, provided it allows the champion to be glorified. In June 1991 at Roland Garros, the day after a five-set victory against Agenor, Connors faced Chang: The age- difference was enough to make him the public's favourite. When, being led by two sets to one, he managed to equalize, the stands accorded him a real triumph. Exhausted, he finally abandoned at the beginning of the fifth set, saying to B. Rebeuh: "If you want to take my place, go ahead, l'rn through". Far from belittling him, his decision made him into the hero of the 1991 French internationals. "Connors dies standing up, thundering applause and tons of 
sadness accompany him as he heads for the changing- rooms" writes M. Baupere the next day for "L'Equipe magazine". The greatest hero's reputation can also thus sink. In $1991 \mathrm{~F}$. Huster, from his viewpoint as an actor, commented on the refusal of the four-time European football champions, Milan, to finish their quarter-final match against "Olympique de Marseille" because of defective lighting, exclaiming: "Look at them, that's shameful, in fact it's a disgrace, it's disgusting to do that in front of millions of young people". ${ }^{4}$

It is not defeat that G. Holtz (the famous French T.V. sports commentator) holds against the Milan team, but rather "to finish like that and to leave by the back door". For B. Tapie the transgression is so enormous that he tries to clear his counterpart, Berlusconi: "He's a lord, he'd never lower himself to that, I know him, we would have had the same opinion about it". Note the use in the three commentaries of the neutral form "that". it designates, in this context, a referent that the speaker cannot or does not wish to name. The persistent use of "that" throws the hideous act into the "unnamable"! The fact that players such as gullit or Van Basten, known for their fair-play, lower themselves to "that" shows that any moral being is capable of weakness when under pressure. Because the result of any test is uncertain by definition, the greatness of those participating in it is equally so. (A match with no uncertainty is a real test neither for the winners nor for the losers).

For his part, H. Leconte used the strategy of transforming defeat into a temporary drop in performance, implying that he could do better or that he did not go all the way. Here, it is the ability to keep going that underlies the heroism of the loser. In fact, the sports challenge still functions today in a medieval way, in which the oath sworn is as good as the act accomplished, in that the one presenting or taking up the challenge thereby commits his honour. If nothing scares Leconte, ever self-confident, he nonetheless hardly ever keeps his ward. (At least up until the final of the 1991 Davis Cup ). Perceived as being the "frog who wanted to be as strong as an ox", he suffers a fiduciary crisis, sanctioned by his weak October mark for "heroism". It is not surprising then, that when he wins the Davis Cup in Lyon, the press highlights the promise made to his son and the fulfilling of his commitment to his captain, who was counting on him. "Papa, win the cup and give it to me!" ${ }^{5}$ The author of this moving letter is only five years old. His name is Maxime. He's Henri's son". "Papa, bring home the cup for me, and Leconte did". These are variations on the theme of challenge successfully undertaken. The increase in Leconte's "heroism" mark (up 4 points) although the biggest increase in the December marks still only allowed him to come up to the average. Thus, in spite of a device intended for his glorification, he remains well below J. Connors' mark. Heroism in thus not in the results themselves. Connors abandons, Leconte wins, but in formulating the account, failure, defeat and victory, Leconte seems deprived of the fruits of his revenge.

\section{"Cantona/the Duschesnays" or How to Become Greater Through Undergoing an Injustice}

In referring to is human but deliberately to allow oneself to be misted is unforgiveable. Thus, a threshold is crossed in the scale of injustices when the repetition of errors appears to reflect a deliberate intention. In this regard, the signals received from the Duchesnay's and from Cantona are practically identical in their form, apart from one detail: the deindividualiation of the complaint. The Duchesnay's do not complain in the narrative framework, that the meaning is reversed. One passes from appreciation to deprecation.

When the Duchesnay's complain, they do not complain about straight forward errors, but about schemes hatched by the jury At the European championship in Leningrad, they knew that they could not do better than a bronze medal, their direct competitors being Soviets. The marks, euphemistically qualified as being "strange" or "odd", appeared to them to be orchestrated behind the scenes. For the judges, everything could serve to justify disgrace: The choreography, the music and even the costumes. Far for accepting what seemed to them to be purely arbitrary, the skaters protested in their own way by becoming allied with the public. The author of this type of denunciation will only be successful if, written by L. Boltanski, "he can win the largest possible number" to his cause. So the champions can only expect an apparently injust decision - to be reversed if an actor more important than the judges, in this case public opinion enters the dispute (Boltanski et al 1984, Boltanski 1990). This exemplary case satisfies a prerequisite of "deindividualisation", in that it shows that the judges' persecution does not affect the general and universal values of skating. From the moment that it is no longer the skaters but their innovation that is being sacrificed for the sake of tradition, the jury finds itself in the dock, subjected to the verdict of the public (whistles, gibes, mocking). To accomplish such a reversal of the accusation, it is imperative that the skater have the full support of the spectators. "You don't ask 
yourself whether you're going to win, but whether the public will like your performance" ${ }^{6}$ declare the Duchesnay's before each competition. "When Isabell and Paul came on with a long, flowing glide towards the middle of the rink, spectators were suddenly seen to stand up, so excited that they could have thawed Saint-Laurent all by themselves! This quest for perfection and that breath of freedom embody their four-year struggle to gain recognition for their style and talent," ${ }^{7}$ reports A. Billouin in Munich in March 15th, 1991.

Cantona's protest does not satisfy the formal constraints defined above; he gets straight into an argument without using an intermediary to complain on his behalf. His reactions are never manifested in the name of the general interest, but in his own individual interests: as such they are classified as being unacceptable moodiness. When on August 20, 1988, he declared "l'1l never play for the French team for as long as H. Michel is a selector; I hope he realizes that he's the most incompetent selector in the entire football world" 8 , the sports media did not spare their most critical language in condemning his attitude. One journalist spoke of a "senseless act", "having a fit". In short, difficulties in the judging of skating and in football selection can be united in the same "semiotic square" composed of four "actors" (Boltanski 1990): The victim (the wronged sportsman), the denunciator (the media, the sportsman himself), the saviour (public opinion) and the persecutor (judges, referee, selectors). The victim no longer recognises the legitimacy of the judgement, so he appeals to the media. These spokesmen influence public opinion, which in turn rises against the "persecutors". The latter, be they judges or selectors can choose between three attitudes:

- to disregard public opinion which amounts to defying it

- to try to enlighten the public by justifying their position

- to go along with the public opinion.

\section{"Arthaud and Daboville" or How to Become Greater Through the Pursuit of a Goal}

The motives which drive these two champions to cross the oceans are quite similar: "trying to go to one's limits", "live your passion to the full" ... In both cases, the same desire prevails. We can clearly see in the risk-running signs of ordealistic behaviour. F. Arthaud confides that she set out to find out who she really is. For his part, G. Daboville states: "I do all of this for myself, to discover sensations and emotions through solitude to discover myself" ${ }^{9}$. Different approaches to the same quest for the truth about oneself, a sort of holy grail for the modern man. But for an identical account, Daboville gets an additional amount of "heroism" in the marks. Why? it seems to us that the perception of the story of the quest as belonging to a masculine world is the cause of this difference. F. Arthaud voiced this opinion when she said: "When Alain Delon said on live television Florence has really got what it takes, I admit I took it as a compliment. When a bloke says that someone's got nerve, it's real sign of admiration, and all the more so when he's talking about the girl." 10 Thus the world of the quest is full of virile images and we find it hard to see a bearded, armoured knight in an attractive young woman.

\section{"Tiozzo/Rives" or How to Shed One's Blood in Order to Become Greater}

Blood is the symbol of honour. It give backbone to the account of boxers and rugby-players. All offences call for a purifying shedding of blood. Blood al one will wash away such an outrage, avenge me, avenge thyself orders Don Diègue his son in "Le Cid" (Act 1, Scene 5). On the other hand, shedding one's own blood amounts to guaranteeing one's honour. J.C. Tiozzo confides that he learned this lesson after his defeat against V. Cordaba: "He hurt me really, he even broke one of my teeth. That's incredible - two years ago my dentist thought he wouldn't be able to extract it. And he went and tore it out with a punch! Amazing! Even the steel pin that held the tooth in place was twisted inside the jaw." ${ }^{11}$ But the demonstration of courage also reminds us that you can't expect your opponent to bleed if you're not prepared to be offended. It's noteworthy that the verb "offend" and its "parasynonyms", "upset" and "hurt" are not activated by the offender but by the offended person's capacity actually to fee! the offense. He is one who actually gets ruffled, to decline a pronominal series? During the 1983 match between France and Wales, Rives playing with a split scalp, did not complain, but rather quite the opposite: "This time you can say, I play a bloody match, everyone's allowed to shed their blood as they see fit. When you see what they take up front, you say to yourself, we can show a bit of courage too." ${ }^{12}$ Thus, whoever remembers the pictures of J.P. Rives bleeding profusely, as if to transmit his strength to the forward line, understands that in Rugby, shedding one's blood is not simply a sign of suffering, but also of life. For Rugby players, (as for the Australian aboriginees) the gift of blood is a 
source of vitality. Blood is essential to leave a trace; the blood-stained shirt will remain after the event as an indelible mark which etches and captures the other players, in an indestructible bond. We are not here undetermining the generosity of these "blood- givers" quite the opposite, by demonstrating that their wounds obey fundamental anthropological laws. Facial cuts ripped-out teeth form part of the initiation rites of many ethnic groups signifying gratitude and courage. In whatever culture he may be, man invents rituals for the shedding of blood and hopes to benefit from them: for fertilising the earth, for growth, for strengthening, for sealing an oath or for establishing a covenant.

\section{Conclusion}

Without a doubt, champions are distinguished not only by their results, but also by their virtue, and become real heroes only if they are able, whether through defeat or victory, to win our esteem. Consequently, there are two ways of magnifying a champion- through an exploit or through the athlete. The height of admiration for an exploit lies in the record (F. Arthaud). The height of celebration for an athlete lies in his greatness in defeat (J. Connors). Going beyond the apparent infatuation of the public with such a sportsman, the semiological approach has enabled us to attribute a meaning to the associations revealed by analysing the correlations. The latter may be interpreted as being narrative frameworks that enable us to replace the traditional "fabulous sports stories" with the figures of casuistry used in the glorification of champions.

\section{Figure 6}

\begin{tabular}{|l|l|l|}
\hline Celebrated figures & Athlete, heros, saint & Exploit, performance \\
\hline Reference values & life as a moral example & the record as a moral example \\
\hline Suggested feelings & admiration, devotion & respect \\
\hline narratives forms & epic, hagiography & technical rationalization \\
\hline Messages & "to be on the stadium as in life" & "to be in life as on the stadium" \\
\hline
\end{tabular}

\section{Notes}

1 Only readers who claimed to buy "L'Équipe" more than three times a week were able to participate.

2 Severa! storys can take a single form.

3 Coaches when it's difficult ask to their men to show that they are real men.

4 Television "Stade deux": March 24th, 1991 Antenne deux.

5 Journal "Paris-Match", no. 2533, December 1991.

6 Billouin, A.: Le coup de coeur des Duschesnay,l'Équipe, 15 Mars 1991, p. 9.

7 Kristoffi, A.S.: "The judges", Revue le sport no. 21, March 1990, pp. 44-45.

8 L'Équipe, December 11, 1991.

9 L'Équipe magazine no. 501, June 1991.

10 "Sport passion" TV News, December 18, 1991.

11 Journal l'Équipe, April4, 1991.

12 Carducci, J., Entretien and Rives, J.P.: Journal l'Équipe, March 21, 1983, p. 5.

\section{References}

BARTHES, R., 1985: L'aventure sémiologique. Paris. Seuil.

BLOOR, D., 1982: Sociologie de la logique ou les limites de l'épistémologie. Paris. Pandore.

BOLTANSKI, L., THEVENOT, L., 1991: De la justification. Paris. Gallimard.

BOLTANSKI, L., 1990: L'amour et la justice comme compétences. Paris. Métailié.

ECCO, U., 1985: Lector in fabula, le rôle du lecteur ou la coopération interprétative dans les textes narratifs. Paris. Grasset.

FRESNAUT, P., 1993: L'éloquence des images. Paris. PUF.

GREIMAS, A. J., 1983: Du sens II. Paris. Seuil.

GREIMAS, A. J., FONTANILLE, J., 1991: Sémiotique des passions. Paris. Seuil.

LEBRETON, D., 1991: Passion du risque. Paris. Métailié. 